\title{
To Make Christianity More Iranian. Studying the Conversions to Christianity in Iran in the Early Pahlavi Period
}

\begin{abstract}
Focusing on the early Pahlavi period the article is aimed at showing the tendencies and processes of development of Christianity among the Iranians as well as the circumstances under which the Protestant believes were communicated, debated and assimilated by the Iranian converts. Adopting the historical methods for describing the social changes that occurred in Iran as a result of the authoritarian policy of the Iranian monarch Reza Shah the article reveals the concept of conversion as a change of values arguing that the converts constructing and imagining their identity remained Iranians by keeping the most valuable feature - the Persian language. Thus, the religious conversion was associated with the concept of Iran-ness (iraniyyat) yet an alternative to the state national policy at that time.
\end{abstract}

Keywords: Iran, Reza Pahlavi, Christianity, Protestantism, religious conversions

Religious conversion as a field of study abounds in various theoretical and methodological approaches focused on its psychological, theological, anthropological and social aspects. ${ }^{1}$ Yet conversion from Islam to Christianity still raises a lot of questions not only of a religious nature but of a cultural or even political character as well. This article is aimed at showing briefly the tendencies and circumstances of changing religious affiliations in Iran in the early Pahlavi period - in 1920s and $1930 \mathrm{~s}$ - in the historical context of the great social changes occurring among Iranians at that time. Such changes were caused by the strong authoritarian policy of Reza Khan, who took power as the prime minister after the 1921 coup, overthrew the last of the Qajar kings and became Reza Shah Pahlavi in 1925. His rule lasted till 1941. The changes which the Iranian society and its various representatives faced during Reza Pahlavi's reign may be described as 'revolutionary'. The reforms, in fact implemented by force, aimed at transforming the society into

\footnotetext{
1 See: L. Rambo, Understanding Religious Conversion, Yale University Press, New Haven 1993.
} 
a modern one, as it was imagined by the Iranian shah. The transformation can be associated with conversion - understood as the changes of values.

The official state policy with its main idea of the 'transformation' of the society should be studied together with the missionary activity conducted in Iran by the British and American missionaries, whose core idea was 'conversion'. By no means are the examples of the behaviour of the converted people in the new socio-political and religious reality of smaller significance, as they may become useful for the further study on the relations between nationalism and religion, the religious change in the context of modernization and political shift, or on the strategies of defining the culture and re-imaging the social and cultural Self. It is also interesting to know how the knowledge of conversion and its nature was developed, how the converts were imagined by the missionaries and how they imagined the missionaries' role in their conversions. It is a problem of communication.

Although represented by different churches in Iran, Christianity became a missionary religion aimed at bringing Muslim converts only due to the influence of the Protestant missionaries who started their missions in $19^{\text {th }}$ century in that country. ${ }^{2}$ The most active were Presbyterians in the north of Iran and Anglicans in its southern part. ${ }^{3}$ Anglicans, with their missionary organization based on the evangelical concepts - the Church Missionary Society - in particular, worked predominantly among the Iranian Muslims. ${ }^{4}$

The proposed approach to the problem of conversion is of a historical character and, which seems quite natural, adopts a historical approach. It has also been enriched with some elements of the anthropologically oriented study of religious conversion along with some concepts of the sociology of knowledge. The historical nature of such research created a necessity to explore archival materials. Among them the Church Missionary Society Archives held at the University of Birmingham (hereafter referred to as CMSA), Archbishop of Canterbury Archives held in the Lambeth Palace Library in London (hereafter referred to as LPL) should be counted. ${ }^{5}$

The main problem of such an approach lies in the lack of self-representation of the converts in the archives, which makes the study of the converts' narratives practically impossible. Such a situation, i.e. the representation of the converts, was typical of the early Pahlavi period, but changed later, in 1940s, when the Christian press was circulated in Iran in the Persian language and the first con-

2 The history of the Protestant missions is described in: M. Bradley, Iran and Christianity. Historical Identity and Present Relevance, London-New York 2008; A.Ch. van Gorder, Christianity in Persia and Status of Non-Muslim in Iran, Plymouth 2010.

3 See: M. Rzepka, Apostołowie nowoczesności. Protestantyzm w Iranie w okresie autorytarnej modernizacji, Kraków 2019, p. 55.

4 J.H. Linton, Evangelism in Persia, "The International Review of Missions" 1931, no. 29, pp. 84-91. General information on the Anglican Church in Iran: H.B. Dehqani-Tafti, Episcopal (Anglican) Church in Persia, [in:] Encyclopcedia Iranica, vol. 8(5), pp. 510-512; M. Rzepka, Apostołowie nowoczesności..., pp. 101-117.

5 To expand the research perspective also materials from American archives, especially the ones corresponding with the American missionary initiatives in Iran should be included - like the collections of the Presbyterian Historical Society, Philadelphia. 
verts' testimonies written by themselves appeared. The following study is part of a broader project on the conversions to Christianity in Iran, whose main aim is to compare the quantity and quality of conversion in two periods of the modern Iranian history divided by the Islamic Revolution in $1979 .{ }^{6}$

\section{Conversions to Christianity and Missionary Strategy}

While raising the question on the missionaries and their attempt to make Christianity acceptable to Iranians it is hard to avoid another one: how they categorized Iranian culture and what tasks they supposed to be obligatory for the potential converts. $^{7}$ Such problems correspond with the knowledge of the mechanism of conversion and missionary understanding of its cultural and social conditions. It seems that missionaries relied mostly on their intuition rather than on the proper research in this field, in fact, the concept of contextualisation, and contextually oriented missions belong to the later period.

Two main aspects of the missionary activity played a crucial role in transmitting Christian religious values. They were: education, which may be considered an initial step towards religious conversion, ${ }^{8}$ and emancipation of the Iranian women. ${ }^{9}$ Education was connected, especially in the missionary presumptions, with the Bible itself, its printing, distribution and popularization, which might have created at the same time quite new attitudes towards the knowledge among mostly illiterate Iranian population, offering them a self-converting tool accessible just by reading. Emancipation, however, was not only related to the new perception of women in the Muslim society but to the new idea of an Iranian family. The former changed the mental and intellectual capability, while the latter - social and cultural habits.

Considering the development of the Iranian society at that time and the strong traditional feelings preserved among Iranians, the missionary projects focused on the social change seemed to be ambitious and 'revolutionary' at the same time.

${ }^{6}$ The conversions to Christianity after the revolution have already been subject to research done by Duane Alexander Miller (Power, Personalities and Politics: The Growth of Iranian Christianity since 1979, "Mission Studies" 2015, vol. 32[1], pp. 66-86); Johan Leman (A 'Lucan Effect' in the Commitment of Iranian Converts in Transit. The case of the Pentecostal Iranian Enclave in Istanbul, "Revue des mondes musulmans et de la Méditerranée" 2007, no. 119-120, pp. 101-114); Sabnem Köser Akçapar (Conversion as a Migration Strategy in a Transit Country: Iranian Shiites Becoming Christians in Turkey, "International Migration Review" 2006, vol. 40[4], pp. 817-853); see also: M. Rzepka, Prayer and protest. The Protestant Communities in Revolutionary Iran, Krakow 2017, pp. 171-206.

7 Among the missionary writings we can also find documents and materials indicating the missionary attempt to understand the needs of the converts, in the meanwhile is a good example of the missionary self-conciseness, see: J.Ch. Wilson, Love must win Persian Converts (An Interesting Survey), "The Moslem World" 1926, no. 16(1), pp. 25-36.

8 J.H. Linton, Evangelism through Schools in the Near East, "The Muslim World" 1932, vol. 22(1), pp. $5-15$.

9 G.E. Francis-Dehqani, Religious Feminism in an Age of Empire. CMS Women Missionaries in Iran 1869-1934, Bristol 2000; M. Rzepka, Apostołowie nowoczesności..., pp. 288-306. 
However, we cannot neglect the assumption of power by Reza shah in 1920s and the consequences of the reforms he introduced and to which he tried to persuade Iranians during his reign. Education and emancipation became two main foundations on which he built the new modern and westernized Iranian identity. The difference between missionaries and state policy lied in the role of religion in the society. The Pahlavi regime marginalized religion, the dominant Iranian religion Islam, while missionaries tried to replace Islam with Christianity. Undoubtedly, these two attempts raised objections among traditional Iranian elites consisting mostly of the Shia clerics. What might have been the strongest missionary impact on society - their efforts to improve social life of the Iranians, was already part of the state policy. As follows, the missionaries and converts who joined them faced unpredictable reactions from the Iranian Muslims categorizing Islam as inseparable part of the Iranian soul and from the Iranian authorities with their overwhelming concept of nationalism.

It seems that the marginalization of Islam by Reza Pahlavi and the open conflict with the Shia clerics might have created proper conditions for spreading Christianity among Iranians filling the religious vacuum caused by his authoritarian and unreligious policy. However, Christianity lost its attractiveness in the Iranian eyes - if it ever had any - by its 'otherness' perceived by both the Iranian nationalists and the traditionally oriented Iranians, who felt the state pressure to reject Islam, and therefore, their religion, Islam, became the purpose of care, the religion of protest, as the Shia Islam was in the past.

How, subsequently, did the Iranian converts - very few in number - define their identity and culture, how did they imagine Christianity as it became the religion of their choice, what was their social background, to which class or group did they belong?

\section{Conversion: Communication and Relation}

The religious conversion always occurs in a certain communicational context and the relations between the converting person and the one to be converted resemble the process of learning, imitating and expressing one's self in the frame of a given pattern. In fact, converts use the style of expressing their conversion, categorizing it in the terms which they learn. In the case of the Iranian converts the relation with the missionaries is very important. In other words, the conversion created a network of dependencies and caused a problem of authority. Such authority was legalized and transmitted in different ways. One of them was the idea of a conference as a platform of exchanging thoughts and opinions between missionaries and converts at the same time being a mode to strengthen their faith, create - we may say - their Christian identity. ${ }^{10}$ Such a conference was of a different character-inter-church or just church assemblies. The inter-church conferences organized in Presbyterian and Anglican cooperation were held several times in the early

10 J.Ch. Wilson, The All-Persia Church Conference, "The Moslem World" 1928, no. 18(2), pp. $159-166$. 
Pahlavi period - 1925, 1927 and 1931. The dates are important as the first one corresponds to the formal change of dynasty in Iran, whereas the second one was organized as an answer to the shah's plans to nationalize schools in Iran.

Talking about the Iranian converts who were aware of the changes in their country, who were part of such changes, and who saw the clash between different concepts of identity, the question of authority seems to be unavoidable.

The above-mentioned network of dependencies involved the converts in quite different relations, such as: 1) the relations with the missionaries, the foreigners in their country, who obtained an authority as the converting ones, 2) the relations with the state authorities, who treated foreigners expressing national feelings with suspicion, and treated the converts more or less as national traitors, and 3) the relations with their rejected religious culture personified by the Shia mullahs, clerics, who rejecting the state policy criticised a missionary activity and treated the converts as apostates. The converts, undoubtedly, had to negotiate their identity coming in contacts with the representatives of different groups. The question is what the Iranian converts treat as a value which helps them to preserve their Iranian identity.

\section{Converts and Conversion: Quantity and Quality}

Another question is how many converts were living in Iran at that time. According to Anglican bishop in Iran James Linton the total number of the converts in 1920s did not exceed 500. In his letter to the Archbishop of Canterbury on $6^{\text {th }}$ January 1926 he wrote:

The present number of converts in the whole mission (4 stations) including baptized children of converts, is about: men -206 , women -190 , children -25 . Total over 420 , of whom about 350 are in good standing. This excludes converted Jews. ${ }^{11}$

Such information indicated the number of the converts who joined the Anglican church, and it seems to have been kept at this level - of 500 people - till the end of Reza Pahlavi reign. The four missionary stations were located in the central and southern parts of Iran: in Isfahan, Shiraz, Yazd and Kerman. The numbers of the male and female converts are almost equal. However, the reason why the percentage of female converts was relatively high is the special mission to the Iranian women.

The important information is hidden behind the phrase 'good standing'. It assumed that some regulations were accepted to justify somebody's 'standing' in Christianity. We cannot find, however, the pattern of conversion in this letter, but we may agree that one to be called a convert had to accept some Christians doctrines, the absolute authority of the Bible, and to be baptized, which became a visual sign of one's conversion. The problem was in the existence of two main Protestant churches in Iran at that time: Presbyterian and Anglican. The converts paid little attention to the differences in their ecclesiology and suggested the 
Church union. The idea of a union expressed at various inter-church conferences remained unachieved. This example helps us understand how the converts were categorized according to the Church to which they joined. The Archbishop of Canterbury sending his response to bishop Linton treats the converts with some suspicion: "In the first place, it is to me almost incredible that we should be able to trust the Persian members, without control and guidance." 12

Even the letter written at the end of 1930s shows that the opinion about the converts dominant among missionaries is that they are not prepared to take responsibility for their own church. Bishop Thompson states: „The few converts there were had not yet shown any desire for self-expression or mutual interdependence." 13

Missionary attitudes towards the Iranian converts depended on: 1) their work which was associated with the social activity: establishing hospitals and schools and 2) treating education as a missionary tool, it needed more time, especially in Iran with a very high rate of illiteracy, to prepare a person to learn theology.

It seems that the first converts were granted benefice of the missionary social work and belonged to marginalised or poor social groups, including women. For them conversion might have meant improvement of their social status. The other group of converts were the Iranians involved in the British enterprises in Iran. The refinery in Abadan established and run by the British and South Persian Rifles was very important.

The modernization experienced by Iranian people under Reza Pahlavi had a practical impact on the missionary work. The newly built roads and railroads facilitated communication between cities, linked unreached areas, and, on the other hand, influenced the self-imagination of the Iranians who showed deeper national consciousness. Changes and development of the Iranian society made the missionaries hopeful to spread their massage. They expressed such hopes and expectations in their letters and books. One of them titled Something new in Persia by Hoare, brought a detailed description of the country with useful information about the missionary work. ${ }^{14}$ However, it was the Bible in the Persian language that was still seen as the best missionary among the Iranians.

The missionary beliefs that the Bible in a native language was able to bring people to Christianity showed the common presumption of the importance of the Persian language in their work among Iranians. What was more and quite unexpected to the missionaries, was the fact that the Persian language became the tool of the nationalistic policy conducted by Reza shah, the object of inclusion to or exclusion from the so-called Iranian nation. The language and the Bible raise some additional questions concerning literacy among Iranians. As I have mentioned, one of the main missionary activities was establishing schools, therefore the Iranian government aimed at the same. Prior to the new regulation abolishing the

${ }^{12}$ LPL, Douglas 213, Archbishop Douglas to bishop Linton, 29th January 1926.

${ }^{13}$ LPL, Lang 63, ff. 164-169, Thompson, Memorandum on the Union of the Church in Iran-April 1937.

14 J.N. Hoare, Something New in Iran, London 1937. 
missionary schools issued in 1927 the total number of the schools established by British and American missionary was $2620 .^{15}$

It seems that education became a battleground for Iranians' mind and soul. The converts to Christianity started to define themselves not only through the lens of the Bible but also through the nationalist idea. James Linton referred to this in his letter saying:

The same National Consciousness which is showing itself in the political sphere is equally evident in the Church. Persian Christians are going to show themselves intolerant of outside control, and this comes out in the findings in one or two places. For example, in the desire to get a Form of Worship 'better adapted to the Persian genius', and in their feeling that the United Church of Persia should not be subject to the jurisdiction of any existing part of the Church. $^{16}$

It is clear that such feelings were expressed rather by educated Iranian members of the Christian church. Linton added: "Some of very best Persian Christians showed the most revolutionary spirit in this matter."17

The questions of literacy, the language and the Bible should be raised again. Every year some of 40 thousand Bibles were distributed in Iran. Missionary press and reports from the 1930s abound with the stories about one of the Iranian converts - Hajji Hassan, who changed his name to Mansur Sang. ${ }^{18}$ To make Iranians familiar with the Bible he worked with the British and Foreign Bible Society selling the Bible for a reasonable price of 1 penny. ${ }^{19}$ What is interesting in the context of the man working every day with the printed word is the fact that being an illiterate person he could not write nor read any word from the Book he was selling, but he would open the Bible and - as one of the missionaries said - "read" it from his mind. It also indicates the importance of not only the spoken language but also the written words positively valorized by the Iranians. In his book, Richards, a British missionary, called persons like Sang 'Living Epistles'. But in an oral, not literal society words play a crucial role in constructing the Self. Richards counted several converts who immediately changed their names after conversion to manifest their new identity, some of them were easy to understand like: Masih (Arabic term for Christ), Salibi (from salib - Arabic term for cross), some might cause some confusion like the name Prot (which was a short form from 'protestant'). ${ }^{20}$ We may assume that the Persian language helped the Iranian converts to keep their cultural identity when they became Christians.

As it has been mentioned above the state policy caused strong opposition toward the reform project among the Iranian Shia clergy. They - as a historian of the

15 LPL, Davidson 2015, Memorandum on Missionary Freedom in Persia, $9^{\text {th }}$ November 1927.

16 LPL, Davidson 2015, Linton to Archbishop Davidson, $27^{\text {th }}$ August 1927.

17 Ibidem.

18 W. McElwee Miller, My Persian Pilgrimage. An Autobiography, Pasadena, California 1995, p. 64; M. Rzepka, Apostołowie nowoczesności..., pp. 272-276.

${ }^{19}$ CMSA, ACC254 Z2, Mansur Sang; W. McElwee Miller, The Muslims Meet Christ, Grand Rapids, Michigan 1969, pp. 113-124.

20 J.R. Richards, Open road in Persia, London 1933, p. 36. 
Reza Pahlavi period Mohammad Faghfoory presented in his article ${ }^{21}$ - resituated the Shia idea called taqiyya, which means dissimulation, or permission to hide beliefs to escape persecution. It is a culturally motivated behaviour completely unacceptable in Christian ethic.

James Linton in one of his letters gave an example of an Iranian convert:

One young Persian Christian was an officer in South Persian Rifles. On the anniversary of the death of Hussein commonly called 'the day of killing' in order to escape persecution he beat himself with chains as the Moslems do. This was equivalent to a denial of his Master as it was done to pretend to be a Moslem. ${ }^{22}$

It is not the place to discuss the value of Shia most important holiday - Ashura and the perception of it among Iranian converts to Christianity. But an important issue to underline is the necessity of confirmation of the once made conversion to Christianity and its contextualization in the converts' lives.

\section{Conclusions}

This short article allows us to draw some conclusions. First of all, the Iranian converts to Christianity in the early Pahlavi period constituted a very small but highly differentiated group of both illiterate and educated members, male and female Christians, people from the cities and from rural areas. Some of them were dependent on missionaries who helped them to improve their social position, others, however, showed more independent thoughts demanding the independent Iranian church led by a native Iranian. Such demands reflect the official policy run by the state at that time and, in fact, the idea of nationalism and its various forms shared by a number of Iranians. Thus, the conversions to Christianity in the Pahlavi period should be interpreted as a starting point of the indigenization or even ethnicization of Christianity among the Iranians.

During the reign of Reza Pahlavi, it became clear that the converts debating, defining, constructing and imagining their identity remained Iranians by keeping the most valuable feature - the Persian language. Their conversion is also one of the concepts of Iran-ness (iraniyyat) alternative to the state nationalism and similar category of Shia religious nationalism. The main concept which is still valuable among the Iranian converts expressed in the name Persian-speaking Christians, the concept which by no means is rooted in the changes occurring in Iran in the first half of the twentieth century.

${ }^{21}$ M.H. Faghfoory, The Ulama-State Relations in Iran: 1921-1941, "International Journal of Middle East Studies" 1987, no. 19(4), pp. 413-432.

${ }^{22}$ LPL, MU/OS/5/29/5 Copy of Letter from Bishop Linton of Persia At Baghdad on tour April $16^{\text {th }}$ 1921. 


\section{Bibliography}

\section{Archival Sources}

Church Missionary Society Archive (CMSA), University of Birmingham.

CMSA, ACC254 Z2, Mansur Sang.

Lambeth Palace Library (LPL), London.

LPL, Douglas 213, Linton to Archbishop Douglas, $6^{\text {th }}$ January 1926.

LPL, Douglas 213, Archbishop Douglas to Bishop Linton, 29 ${ }^{\text {th }}$ January 1926.

LPL, Davidson 215, Linton to Archbishop Davidson, $27^{\text {th }}$ August 1927.

LPL, Davidson 215, Memorandum on Missionary Freedom in Persia, 9th November 1927.

LPL, Lang 63, ff. 164-169, Thompson, Memorandum on the Union of the Church in Iran-April 1937.

LPL, MU/OS/5/29/5 Copy of Letter from Bishop Linton of Persia At Baghdad on tour April $16^{\text {th }} 1921$.

\section{Other Materials}

Akçapar S.K., Conversion as a Migration Strategy in a Transit Country: Iranian Shiites Becoming Christians in Turkey, "International Migration Review” 2006, no. 40(4), pp. 817-853.

Bradley M., Iran and Christianity. Historical Identity and Present Relevance, LondonNew York 2008.

Dehqani-Tafti H.B., Episcopal (Anglican) Church in Persia, [in:] Encyclopoedia Irani$c a$, vol. 8(5), pp. 510-512.

Faghfoory M.H., The Ulama-State Relations in Iran: 1921-1941, "International Journal of Middle East Studies" 1987, no. 19(4), pp. 413-432.

Francis-Dehqani G.E., Religious Feminism in an Age of Empire. CMS Women Missionaries in Iran 1869-1934, Bristol 2000.

Hoare J.N., Something New in Iran, London 1937.

Leman J., A 'Lucan Effect' in the Commitment of Iranian Converts in Transit. The case of the Pentecostal Iranian Enclave in Istanbul, "Revue des mondes musulmans et de la Méditerranée" 2007, no. 119-120, pp. 101-114.

Linton J.H., Evangelism in Persia, "The International Review of Missions" 1931, no. 29, pp. 84-91.

Linton J.H., Evangelism through Schools in the Near East, "The Muslim World" 1932, no. 22(1), pp. 5-15.

Miller D.A., Power, Personalities and Politics: The Growth of Iranian Christianity since 1979, "Mission Studies" 2015, no. 32(1), pp. 66-86.

Miller McElwee W., The Muslims Meet Christ, Grand Rapids, Michigan 1969.

Miller McElwee W., My Persian Pilgrimage. An Autobiography, Pasadena 1995.

Rambo L., Understanding Religious Conversion, Yale University Press, New Haven 1993.

Richards J.R., Open road in Persia, London 1933.

Rzepka M., Prayer and protest. The Protestant Communities in Revolutionary Iran, Krakow 2017. 
Rzepka M., Apostołowie nowoczesności. Protestantyzm w Iranie w okresie autorytarnej modernizacji, Kraków 2019.

van Gorder A.Ch., Christianity in Persia and Status of Non-Muslim in Iran, Plymouth 2010.

Wilson J.Ch., Love must win Persian Converts (An Interesting Survey), "The Moslem World" 1926, no. 16(1), pp. 25-36.

Wilson J.Ch., The All-Persia Church Conference, "The Moslem World" 1928, no. 18(2), pp. 159-166. 